\title{
A New Multi-Criteria Assessment Model Combining GRA Techniques with Intuitionistic Fuzzy Entropy-Based TOPSIS Method for Sustainable Building Materials Supplier Selection
}

\author{
Chun-Ho Chen \\ Professional Architect and Urban Planner, Bachelor Program of Real Estate Investment and Management, \\ Takming University of Science and Technology, No.56, Sec. 1, Huanshan Rd., Neihu District, \\ Taipei 11451, Taiwan; phdchen5598@gmail.com
}

Received: 24 February 2019; Accepted: 9 April 2019; Published: 15 April 2019

\begin{abstract}
A new multi-criteria assessment model is proposed in this paper, which combines grey relational analysis (GRA) techniques with intuitionistic fuzzy entropy-based Technique for Order Preference by Similarity to Ideal Solution (TOPSIS) method, to solve multi-criteria decision making (MCDM) problems and to sort the alternatives. Generally speaking, the supplier selection process, by which buyers choose to find the right supplier of the high-quality products or/and services within the scheduled and quantity, is one of the most important key activities in constructing an effective and timely supply chain. On account of several conflicting attributes on which the knowledge of decision makers is often inaccurate and vague, this is a difficult problem. The contribution of this paper is not only to substitute objective weights of intuitionistic fuzzy entropy for subjective weights directly made by decision-makers in the TOPSIS method, but also to extend and modify this method with intuitionistic fuzzy sets and GRA techniques, and to propose the intuitionistic fuzzy entropy-based TOPSIS method combined with GRA techniques for selecting appropriate sustainable building materials supplier. Finally, we take the choice of sustainable building materials supplier as an example to illustrate the alternative effectively chosen by the intuitionistic fuzzy entropy-based TOPSIS method combined with GRA techniques.
\end{abstract}

Keywords: multi-criteria assessment model; GRA (grey relational analysis) technique; intuitionistic fuzzy set; Entropy-Based Weight method; TOPSIS

\section{Introduction}

Multi-criteria assessment model can be suitable in solving complex problems. In the case of multiple standards, there are a variety of multi-standard technologies to aid decision making. In issues of multi-criteria decision making, decision makers choose the most suitable alternative after rational evaluation of a limited set of independent or interdependent criteria. Atanassov [1-3] improved traditional fuzzy set to the intuitionistic fuzzy sets (IFS) as regards the degree of hesitation since 1986, which is the generalization of fuzzy sets theory [4]. The theory of IFS has been widely used to solve problems related to multi-criteria decision making (MCDM). Grey system theory [5] is a method to explore uncertainty in the case of scare data and has advantages in deductive analysis of uncertain information situation. It has been successfully applied to situations where there is partial information or uncertainty. The grey system theory mainly consists of five facets: grey relational analysis (GRA), grey prediction, grey decision making, grey control and grey planning [6]. In recent years, GRA technology has been applied to solve uncertainties in different fields under discrete data and incomplete information environment [7-14]. GRA technique is one of the common methods for 
analyzing various relationships among discrete data sets and making the right decisions in the case of multiple criteria or attribute situations [15]. The techniques first obtain a correlation between reference sequence and comparable sequences and then sort the alternatives according to the correlation.

Supply chain management (SCM) is primarily about maximizing revenue, reducing manufacturing costs, meeting consumer service, optimizing business process, cycle times and inventory levels, and improving competitiveness, customer satisfaction and profitability [16-21]. Certain factors need to be predefined and implemented in the decision-making process, especially in complex areas such as SCM. In the initial stage of the supply chain (SC), one of the most important projects is to choose the most favorable supplier [22]. SCM has recently received widespread attention from industry and academia.

The main activity of a successful SC lies in effective purchasing mechanisms and functions [17,23-25]. The most important responsibility of the procurement function is to select the right supplier because it saves the organization huge costs [26]. Several approaches have been discussed for the suitability of supplier selection. The supplier selection in the system analysis method includes weighted point method, taxonomy [27,28], vendor profile analysis [29], supplier performance matrix approach [30], matrix approach [31], and analytic hierarchy process (AHP) [32,33]. The supplier selection problem is characterized by complex, multi-criteria, and unstructured nature, and is considered to be a multi-criteria decision-making problem [34-37].

Most of methodologies proposed for addressing supplier selection issues do not seem to solve the unstructured and complex context of current purchasing decision conditions [38]. In the decision-making process, several influencing factors are often ignored and not considered, such as qualitative criteria, ambiguous information, other qualitative criteria and inaccurate preference representations $[39,40]$. Therefore, in response to this dilemma, the solution to the problem of supplier selection has introduced the fuzzy set theory (FST). The application and suitability of FST in supplier selection was explored [41,42]. The concept of TOPSIS method is extended to solve the problem of supplier selection in fuzzy environment [40]. The fuzzy AHP was presented and used to verify the structural model for evaluation rubber industry suppliers by using AHP [26]. Based on the fuzzy theory calculation, a fuzzy multi-criteria group decision-making method for supplier selection was presented [43]. The fuzzy AHP is proposed to effectively solve quantitative and qualitive decision factors in global supplier selection [44].

One of the most famous methods for MCDM, Technique for Order Preference by Similarity to an Ideal Solution (TOPSIS), was proposed by Hwang and Yoon [45]. The TOPSIS method, which considered both positive and negative ideal solutions, is based on the following concept that the chosen alternative should be closer to the positive-ideal solution and farther away from the negative-ideal solution. The TOPSIS method is considered to be an important research topic and has received great attention from the academic community $[46,47]$. However, TOPSIS has its drawbacks because decision makers need to subjectively judge the weighting of the various criteria $[48,49]$. TOPSIS is generally used to sort all alternatives in the final phase [50].

In the choice of supplier issues, both the weight of criteria and the impact of differentiating alternatives on the criteria determined by the decision maker are difficult to accurately and appropriately express by crisp data.

The intuitionistic fuzzy sets (IFSs) proposed by Atanassov (1986) is a suitable method to deal with this challenge in an uncertain environment. IFSs have been successfully applied in diverse fields in recent years such as: decision-making problems [51-62], pattern recognition [63-68], and medical diagnosis [69-71].

Aiming at the problem of supplier selection, an intuitionistic fuzzy multi-criteria decision making with entropy-based TOPSIS method and GRA techniques is proposed. Based on the above analysis, the main investigated topics of this study are as follows:

(1) TOPSIS has its drawbacks because decision makers need to subjectively judge the weighting of various criteria. Therefore, when the decision makers are in intuitionistic fuzzy environment, 
how should we solve the problem of decision makers subjectively setting weights in the TOPSIS method?

(2) The calculation of intuitionistic fuzzy entropy is different from the general measurement of entropy weight. How do we combine the TOPSIS method with intutionistic fuzzy entropy in order to obtain objective weight values?

(3) GRA is a measure of the nonlinear relationship between sequences and can compensate for the deficiencies of TOPSIS method. How should we combine the intutionistic fuzzy entropy-based TOPSIS method with GRA techniques?

In this study, we propose the intuitionistic fuzzy entropy-based TOPSIS method combined with GRA techniques for selecting appropriate sustainable building materials supplier. Entropy-based TOPSIS method based on GRA techniques and intuitionistic fuzzy set has huge chance of success in the supplier selection process. The remainder of this article is divided into five parts. Section 2 introduces the research framework and methodology, and Section 3 we present intuitionistic fuzzy entropy-based TOPSIS with RGA techniques. Section 4 gives a numerical example of sustainable building materials supplier selection. In Section 5, we describe the analysis and discussion of the results associated with our approach. Finally, Section 6 presents the conclusions of the study.

\section{Research Framework and Methodology}

The analytic processes of the research framework consist of four stages, as shown in Figure 1:

Stage 1: Introduce the research background and review literatures and methods.

Stage 2: Begin to establish a new multi-criteria assessment model and then combine this model with intuitionist fuzzy entropy and TOPSIS method.

Stage 3: Extend the TOPSIS method by GRA technology.

Stage 4: Discuss the results and sensitive analysis.

Section 2.1 through Section 2.3 belong to Stage 1, including a review of related methods, such as grey relational analysis (GRA), intuitionistic fuzzy set and intuitionistic fuzzy entropy. As for Section 3 through Section 5, it belongs to other stages.

\subsection{Grey Relational Analysis (GRA)}

The Grey System theory was introduced to the scientific community in 1982 [72]. The goal and application of the Grey System theory is to construct a bridge between the social sciences and the national sciences and fill in the gaps between them. Hereby, Grey System theory is an interdisciplinary academic field [5]. The term "grey" in the theoretical name can be interpreted as a feature between black and white. Hereby, "black" indicates that the required information is not fully available; on the contrary, "white" indicates that the required information is fully available. Grey system theory establishes the connection and correlation between white and black [73].

GRA is a well-liked method for analyzing the relationship between discrete data sets. GRA is also applied in multi-attributes cases for decision making. GRA use the information in the grey system to dynamically quantify and compare factors. According to similarity and variability, this method of contact establishes the relationship among the factors [74]. GRA measures the degree of association among factors based on grey relational grade [75]. In addition, GRA calculates grey relational grade between reference sequence and comparable sequences based on grey relational coefficient. Among the alternatives, the highest value of grey relational grade is the best choice [76-78]. GRA is used to access the relative proximity of each alternative to an ideal solution. According to the degree of similarity between two alternatives, the closer the distance between the actual object and the ideal object, the greater the correlation between the two [79].

Steps of the GRA algorithm [80-82] will be described in Section 3. 


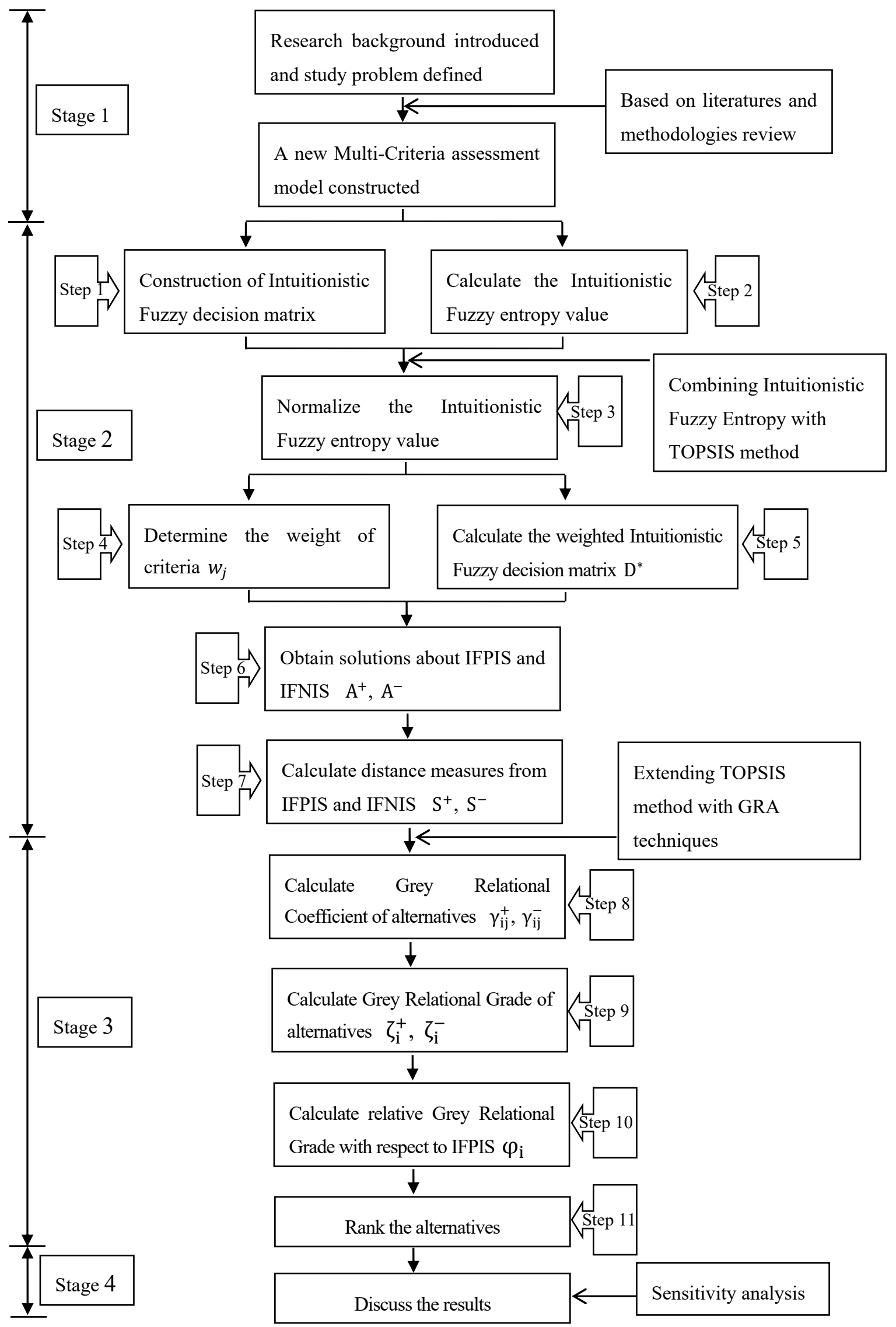

Figure 1. Analytic processes of the research framework. 


\subsection{Intuitionistic Fuzzy Sets}

Intuitionistic fuzzy sets (IFSs) proposed by Atanassov in 1986, which is a suitable way to deal with ambiguity and uncertainty. The degrees of membership, non-membership and hesitancy can be presented in IFSs.

An IFSs A, which is in finite set $X$, has the form as follows:

$$
\mathrm{A}=\left\{\left[\mathrm{x}, \mu_{\mathrm{A}}(\mathrm{x}), \mathrm{v}_{\mathrm{A}}(\mathrm{x})\right] \mid \mathrm{x} \in \mathrm{X}\right\}
$$

where the function $\mu_{\mathrm{A}}(\mathrm{x})$ is the degree of membership, $\mathrm{v}_{\mathrm{A}}(\mathrm{x})$ is the degree of non-membership, and $\mu_{\mathrm{A}}(\mathrm{x}), \mathrm{v}_{\mathrm{A}}(\mathrm{x}): \mathrm{X} \rightarrow[0,1]$, respectively. For each $\mathrm{x} \in \mathrm{X}$,

$$
0 \leq \mu_{\mathrm{A}}(\mathrm{x})+\mathrm{v}_{\mathrm{A}}(\mathrm{x}) \leq 1
$$

Another parameter of IFSs is $\pi_{\mathrm{A}}(\mathrm{x})$, which is the degree of hesitancy of the intuitionistic fuzzy index, indicating whether $x$ belongs to A.

$$
\pi_{\mathrm{A}}(\mathrm{x})=1-\mu_{\mathrm{A}}(\mathrm{x})-\mathrm{v}_{\mathrm{A}}(\mathrm{x})
$$

For each $\mathrm{x} \in \mathrm{X}$, obviously it can be seen that

$$
0 \leq \pi_{\mathrm{A}}(\mathrm{x}) \leq 1
$$

If $\pi_{\mathrm{A}}(\mathrm{x})$ is closer to 1 , knowledge and information about $\mathrm{x}$ is more uncertain, on the contrary, knowledge and information about $\mathrm{x}$ is more certain. Apparently, when $\mu_{\mathrm{A}}(\mathrm{x})=1-\mathrm{v}_{\mathrm{A}}(\mathrm{x})$ of all elements in the universe, the general fuzzy set concept is restored [83].

For every $A, G \in \operatorname{IFSs}(x)$, there are several operations defined as follows [84]:

$$
\begin{gathered}
A \leq G \text { iif } \mu_{A}(x) \leq \mu_{G}(x) \text { and } v_{A}(x) \geq v_{G}(x) \text { for all } x \text { in } X \\
A=G \text { iif } A \leq G \text { and } G \leq A \\
A \cap G=\left\{\left(x, \min \left(\mu_{A}(x), \mu_{G}(x)\right), \max \left(v_{A}(x), v_{G}(x)\right)\right) \mid x \in X\right\} \\
A \cup G=\left\{\left(x, \max \left(\mu_{A}(x), \mu_{G}(x)\right), \min \left(v_{A}(x), v_{G}(x)\right)\right) \mid x \in X\right\}
\end{gathered}
$$

Assuming that $A$ and $G$ are IFSs of the set $X$, then multiplication expression is presented as follows [1]:

$$
\mathrm{A} \otimes \mathrm{G}=\left\{\mu_{\mathrm{A}}(\mathrm{x}) \cdot \mu_{\mathrm{G}}(\mathrm{x}), \mathrm{v}_{\mathrm{A}}(\mathrm{x})+\mathrm{v}_{\mathrm{G}}(\mathrm{x})-\mathrm{v}_{\mathrm{A}}(\mathrm{x}) \cdot \mathrm{v}_{\mathrm{G}}(\mathrm{x}) \mid \mathrm{x} \in \mathrm{X}\right\}
$$

\subsection{Intutionistic Fuzzy Entropy}

Since Atanassov (1986) proposed the theory of IFSs, many scholars began to study the entropy metric of IFSs from various viewpoints. The traditional entropy can measure the recognition of attributes while applied in multi-attribute assessment model. However, on account of the IFSs entropy represents the credibility of the data while applied in multi-attribute assessment model, the definition of IFSs entropy is different from traditional defined entropy [84].

This paper selects the IFSs entropy measure proposed by Vlachos and Sergiadis (2007) [85]. They generalized relative researches and yielded a new measure for entropy of IFSs. It can be articulated as follows:

$$
\begin{aligned}
\mathrm{E}_{\mathrm{A}}(\mathrm{A})= & \left\{\min \left[\mu_{\mathrm{A}}\left(\mathrm{x}_{\mathrm{i}}\right), \mathrm{v}_{\mathrm{A}}\left(\mathrm{x}_{\mathrm{i}}\right)\right]+\min \left[1-\mathrm{v}_{\mathrm{A}}\left(\mathrm{x}_{\mathrm{i}}\right), 1-\mu_{\mathrm{A}}\left(\mathrm{x}_{\mathrm{i}}\right)\right]\right\} \\
& /\left\{\max \left[\mu_{\mathrm{A}}\left(\mathrm{x}_{\mathrm{i}}\right), \mathrm{v}_{\mathrm{A}}\left(\mathrm{x}_{\mathrm{i}}\right)\right]+\max \left[1-\mathrm{v}_{\mathrm{A}}\left(\mathrm{x}_{\mathrm{i}}\right), 1-\mu_{\mathrm{A}}\left(\mathrm{x}_{\mathrm{i}}\right)\right]\right\}
\end{aligned}
$$




\section{Intuitionistic Fuzzy Entropy-Based TOPSIS with GRA Techniques}

Let $A=\left\{A_{1}, A_{2}, \ldots, A_{m}\right\}$ be a collection of alternatives and $C=\left\{C_{1}, C_{2}, \ldots, C_{n}\right\}$ be a collection of criteria, the procedure of intuitionistic fuzzy entropy-based TOPSIS method with GRA techniques can be listed as follows:

Step 1: Establishing the Intuitionistic Fuzzy Decision Matrix In this step, intuitionistic fuzzy value $\mathrm{d}_{\mathrm{ij}}=\left(\mu_{\mathrm{ij}}, \mathrm{v}_{\mathrm{ij}}, \pi_{\mathrm{ij}}\right)$ is obtained and intuitionistic fuzzy decision matrix $\mathrm{D}=\left[\mathrm{d}_{\mathrm{ij}}\right]_{\mathrm{m} \times \mathrm{n}}$ is established. Here $\mu_{i j}$ and $v_{i j}$ are degrees of membership and non-membership of the alternative $A_{i}$ which satisfies the criterion $\mathrm{x}_{\mathrm{j}}$. And $\pi_{\mathrm{ij}}$ is the degree of hesitancy of the alternative $A_{\mathrm{i}}$ which satisfies the criterion $\mathrm{x}_{\mathrm{j}}$.

Intuitionistic fuzzy decision matrix can be presented as follows:

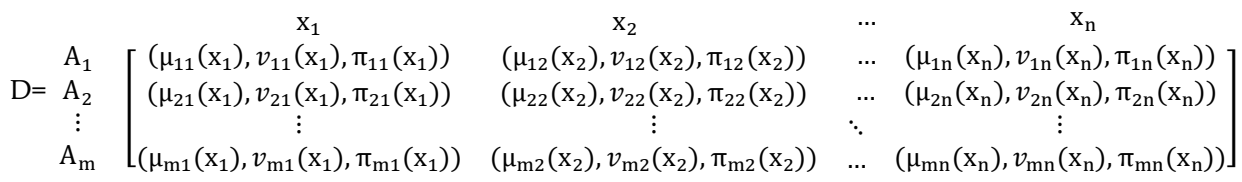

The intuitionistic fuzzy decision matrix $\mathrm{D}$ has $\mathrm{m}$ alternatives and $\mathrm{n}$ criteria. A denotes the alternative and $x$ denotes the criterion.

\section{Step 2: Determining the Intuitionistic Fuzzy Entropy Values}

In this step, measuring method introduced by Vlachos and Sergiadis (2007) is used to calculate intuitionistic fuzzy entropy values.

$$
\begin{aligned}
& \begin{aligned}
\mathrm{E}_{\mathrm{ij}}\left(\mathrm{x}_{\mathrm{j}}\right)= & \left\{\min \left[\mu_{\mathrm{ij}}\left(\mathrm{x}_{\mathrm{j}}\right), \mathrm{v}_{\mathrm{ij}}\left(\mathrm{x}_{\mathrm{j}}\right)\right]+\min \left[1-\mathrm{v}_{\mathrm{ij}}\left(\mathrm{x}_{\mathrm{j}}\right), 1-\mu_{\mathrm{ij}}\left(\mathrm{x}_{\mathrm{j}}\right)\right]\right\} \\
& /\left\{\max \left[\mu_{\mathrm{ij}}\left(\mathrm{x}_{\mathrm{j}}\right), \mathrm{v}_{\mathrm{ij}}\left(\mathrm{x}_{\mathrm{j}}\right)\right]+\max \left[1-\mathrm{v}_{\mathrm{ij}}\left(\mathrm{x}_{\mathrm{j}}\right), 1-\mu_{\mathrm{ij}}\left(\mathrm{x}_{\mathrm{j}}\right)\right]\right\}
\end{aligned} \\
& \mathrm{D}=\begin{array}{c}
\mathrm{A}_{1} \\
\mathrm{~A}_{2} \\
\mathrm{~A}_{\mathrm{m}}
\end{array}\left[\begin{array}{cccc}
\mathrm{E}_{11} & \mathrm{x}_{2} & \ldots & \mathrm{x}_{\mathrm{n}} \\
\mathrm{E}_{21} & \mathrm{E}_{22} & \ldots & \mathrm{E}_{1 \mathrm{n}} \\
\vdots & \vdots & \ddots & \vdots \\
\mathrm{E}_{\mathrm{m} 1} & \mathrm{E}_{\mathrm{m} 2} & \ldots & \mathrm{E}_{\mathrm{mn}}
\end{array}\right]
\end{aligned}
$$

where $E_{\mathrm{ij}}$ represents each entropy value in the intuitionistic fuzzy decision matrix.

Step 3: Normalization of the Intuitionistic Fuzzy Entropy Value

Normalized entropy value is symbolized by $\mathrm{e}_{\mathrm{ij}}$ as follows:

$$
\mathrm{e}_{\mathrm{ij}}=\frac{\mathrm{E}_{\mathrm{i} 1}}{\max \left(\mathrm{E}_{\mathrm{i} 1}\right)}, \frac{\mathrm{E}_{\mathrm{i} 2}}{\max \left(\mathrm{E}_{\mathrm{i} 2}\right)}, \ldots, \frac{\mathrm{E}_{\mathrm{ij}}}{\max \left(\mathrm{E}_{\mathrm{ij}}\right)}
$$

Then new decision matrix can be denoted as follows:

$$
\begin{gathered}
\mathrm{x}_{1} \\
\mathrm{D}=\mathrm{A}_{1} \\
\vdots \\
\mathrm{A}_{\mathrm{m}}
\end{gathered}\left[\begin{array}{cccc}
\mathrm{e}_{11} & \mathrm{e}_{12} & \ldots & \mathrm{x}_{\mathrm{n}} \\
\mathrm{e}_{21} & \mathrm{e}_{22} & \cdots & \mathrm{e}_{2 \mathrm{n}} \\
\vdots & \vdots & \ddots & \vdots \\
\mathrm{e}_{\mathrm{m} 1} & \mathrm{e}_{\mathrm{m} 2} & \ldots & \mathrm{e}_{\mathrm{mn}}
\end{array}\right]
$$

Step 4: Determining Criteria Weights 
Not all criteria are equally important. In this step, following intuitionistic fuzzy entropy measurement proposed by Chen and $\mathrm{Li}[86]$ would be used to obtain the weight vector, that $\mathrm{w}=$ $\left(\mathrm{w}_{1}, \mathrm{w}_{2}, \ldots, \mathrm{w}_{\mathrm{n}}\right)$, where $\mathrm{w}_{\mathrm{i}} \geq 0$ and $\sum_{\mathrm{i}=1}^{\mathrm{n}} \mathrm{w}_{\mathrm{i}}=1$.

$$
w_{j}=\frac{1}{(n-T)} \times\left(1-a_{j}\right), \quad j=1,2, \ldots, n
$$

where $a_{j}=\sum_{d=1}^{i} e_{d j}$ and $T=\sum_{k=1}^{j} a_{k}$. The $a_{j}$ represents the sum of the normalized entropy values which corresponds to the criterion $\mathrm{j}$. Then $\mathrm{T}$ is the sum of $\mathrm{a}_{\mathrm{j}}$, and $\mathrm{n}$ represents the number of criteria.

Step 5: Constructing the Weighted Matrix of Intuitionistic Fuzzy Decision

Based on the following formula proposed by Atanassov [87], the weighted matrix of intuitionistic fuzzy decision is constructed.

$$
\lambda \mathrm{I}=\left(1-\left(1-\mu_{\mathrm{I}}\right)^{\lambda},\left(\mathrm{v}_{\mathrm{I}}\right)^{\lambda}\right), \quad 0<\lambda<1
$$

The weighted matrix of intuitionistic fuzzy decision can be expressed as follows:

$$
\begin{gathered}
\mathrm{x}_{1} \\
\mathrm{D}^{*}=\mathrm{A}_{1} \\
\vdots \\
\mathrm{A}_{\mathrm{m}}
\end{gathered} \quad\left[\begin{array}{ccc}
\left(\mu_{11 \mathrm{w}}\left(\mathrm{x}_{1}\right), v_{11 \mathrm{w}}\left(\mathrm{x}_{1}\right), \pi_{11 \mathrm{w}}\left(\mathrm{x}_{1}\right)\right) & \ldots & \left(\mu_{1 \mathrm{nw}}\left(\mathrm{x}_{\mathrm{n}}\right), v_{1 \mathrm{nw}}\left(\mathrm{x}_{\mathrm{n}}\right), \pi_{1 \mathrm{nw}}\left(\mathrm{x}_{\mathrm{n}}\right)\right) \\
\left(\mu_{21 \mathrm{w}}\left(\mathrm{x}_{1}\right), v_{21 \mathrm{w}}\left(\mathrm{x}_{1}\right), \pi_{21 \mathrm{w}}\left(\mathrm{x}_{1}\right)\right) & \ldots & \left(\mu_{2 \mathrm{nw}}\left(\mathrm{x}_{\mathrm{n}}\right), v_{2 \mathrm{nw}}\left(\mathrm{x}_{\mathrm{n}}\right), \pi_{2 \mathrm{nw}}\left(\mathrm{x}_{\mathrm{n}}\right)\right) \\
\vdots & \ddots & \vdots \\
\left(\mu_{\mathrm{m} 1 \mathrm{w}}\left(\mathrm{x}_{1}\right), v_{\mathrm{m} 1 \mathrm{w}}\left(\mathrm{x}_{1}\right), \pi_{\mathrm{m} 1 \mathrm{w}}\left(\mathrm{x}_{1}\right)\right) & \ldots & \left(\mu_{\mathrm{mnw}}\left(\mathrm{x}_{\mathrm{n}}\right), v_{\mathrm{mnw}}\left(\mathrm{x}_{\mathrm{n}}\right), \pi_{\mathrm{mnw}}\left(\mathrm{x}_{\mathrm{n}}\right)\right)
\end{array}\right]
$$

Step 6: Acquire the Solutions of Intuitionistic Fuzzy Positive-Ideal (IFPI) and Intuitionistic Fuzzy Negative-Ideal (IFNI)

In the TOPSIS method, the assessment criteria can be divided into benefit criteria and cost criteria, respectively. Let $B$ be a set of benefit criteria and $C$ be a set of cost criteria. $A^{+}$is intuitionistic fuzzy positive-ideal solution and $\mathrm{A}^{-}$represents intuitionistic fuzzy negative-ideal solution. Then $\mathrm{A}^{+}$and $\mathrm{A}^{-}$ are acquired as:

$$
\mathrm{A}^{+}=\left(\mu_{\mathrm{A}^{+} \mathrm{W}}\left(\mathrm{x}_{1}\right), \mathrm{v}_{\mathrm{A}^{+} \mathrm{W}}\left(\mathrm{x}_{1}\right)\right) \text { and } \mathrm{A}^{-}=\left(\mu_{\mathrm{A}^{-} \mathrm{W}}\left(\mathrm{x}_{1}\right), \mathrm{v}_{\mathrm{A}^{-} \mathrm{W}}\left(\mathrm{x}_{1}\right)\right)
$$

where

$$
\begin{aligned}
& \mu_{A^{+} W}\left(x_{j}\right)=\left(\left(\max _{i} \mu_{A_{i} w}\left(x_{j}\right) \mid j \in B\right),\left(\min _{i} \mu_{A_{i} w}\left(x_{j}\right) \mid j \in C\right)\right) \\
& \mathrm{v}_{\mathrm{A}^{+} \mathrm{W}}\left(\mathrm{x}_{\mathrm{j}}\right)=\left(\left(\min _{\mathrm{i}} \mathrm{v}_{\mathrm{A}_{\mathrm{i}} \mathrm{W}}\left(\mathrm{x}_{\mathrm{j}}\right) \mid \mathrm{j} \in \mathrm{B}\right),\left(\max _{\mathrm{i}} \mathrm{v}_{\mathrm{A}_{\mathrm{i}} \mathrm{W}}\left(\mathrm{x}_{\mathrm{j}}\right) \mid \mathrm{j} \in \mathrm{C}\right)\right) \\
& \mu_{A^{-} W}\left(x_{j}\right)=\left(\left(\min _{i} \mu_{A_{i} W}\left(x_{j}\right) \mid j \in B\right),\left(\max _{i} \mu_{A_{i} w}\left(x_{j}\right) \mid j \in C\right)\right) \\
& \mathrm{v}_{\mathrm{A}^{-} W}\left(\mathrm{x}_{\mathrm{j}}\right)=\left(\left(\max _{\mathrm{i}} \mathrm{v}_{\mathrm{A}_{\mathrm{i}} \mathrm{W}}\left(\mathrm{x}_{\mathrm{j}}\right) \mid \mathrm{j} \in \mathrm{B}\right),\left(\min _{\mathrm{i}} \mathrm{v}_{\mathrm{A}_{\mathrm{i}} \mathrm{W}}\left(\mathrm{x}_{\mathrm{j}}\right) \mid \mathrm{j} \in \mathrm{C}\right)\right)
\end{aligned}
$$

Step 7: Calculate the Distance Measured from IFPIS (Solution of IFPI) and IFNIS (Solution of IFNI)

In order to measure the distance between each alternative $A_{i}$ from IFPIS and IFNIS, the intuitive separation measurement given by Szmidt and Kacprzyk [88] is expressed by the following calculation:

$$
\mathrm{S}^{+}=\sqrt{\frac{1}{2 \mathrm{n}} \sum_{\mathrm{j}=1}^{\mathrm{n}}\left[\left(\mu_{\mathrm{A}_{\mathrm{i}} \mathrm{w}}\left(\mathrm{x}_{\mathrm{j}}\right)-\mu_{\mathrm{A}^{+} \mathrm{w}}\left(\mathrm{x}_{\mathrm{j}}\right)\right)^{2}+\left(\mathrm{v}_{\mathrm{A}_{\mathrm{i}} \mathrm{w}}\left(\mathrm{x}_{\mathrm{j}}\right)-\mathrm{v}_{\mathrm{A}^{+}{ }_{\mathrm{w}}}\left(\mathrm{x}_{\mathrm{j}}\right)\right)^{2}+\left(\pi_{\mathrm{A}_{\mathrm{i}} \mathrm{w}}\left(\mathrm{x}_{\mathrm{j}}\right)-\pi_{\mathrm{A}^{+}{ }_{\mathrm{w}}}\left(\mathrm{x}_{\mathrm{j}}\right)\right)^{2}\right]}
$$




$$
S^{-}=\sqrt{\frac{1}{2 n} \sum_{j=1}^{n}\left[\left(\mu_{A_{i} w}\left(x_{j}\right)-\mu_{A^{-} w}\left(x_{j}\right)\right)^{2}+\left(v_{A_{i} w}\left(x_{j}\right)-v_{A^{-} w}\left(x_{j}\right)\right)^{2}+\left(\pi_{A_{i} w}\left(x_{j}\right)-\pi_{A^{-} w}\left(x_{j}\right)\right)^{2}\right]}
$$

\section{Step 8: Calculate Grey Relational Coefficient of Alternatives}

Use the following formula to calculate the grey relational coefficient between each alternative and IFPIS:

$$
\gamma_{i j}^{+}=\gamma\left(A_{j}^{+}, A_{i j}\right)=\frac{\min _{i} \min _{j} S\left(A_{j}^{+}, A_{i j}\right)+\rho \max _{i} \max _{j} S\left(A_{j}^{+}, A_{i j}\right)}{S\left(A_{j}^{+}, A_{i j}\right)+\rho \max _{i} \max _{j} S\left(A_{j}^{+}, A_{i j}\right)}
$$

where $\rho$ is the recognition coefficient, $\rho \in[0,1]$, generally let $\rho=0.5$. And $i=1,2, \ldots, m$, and $j=1,2$, $\ldots, \mathrm{n}$.

Use the following formula to calculate the grey relational coefficient between each alternative and IFNIS:

$$
\gamma_{i j}^{-}=\gamma\left(A_{j}^{-}, A_{i j}\right)=\frac{\min _{i} \min _{j} S\left(A_{j}^{-}, A_{i j}\right)+\rho \max _{i} \max _{j} S\left(A_{j}^{-}, A_{i j}\right)}{S\left(A_{j}^{-}, A_{i j}\right)+\rho \max _{i} \max _{j} S\left(A_{j}^{-}, A_{i j}\right)}
$$

Step 9: Calculating the Grey Relational Grade of Alternatives

Use the following formula to calculate the grey relational grade of each alternative:

$$
\begin{gathered}
\zeta_{i}^{+}=\sum_{j=1}^{n} \gamma_{i j}^{+} \times w_{j} \text { and } \sum_{j=1}^{n} w_{j}=1 \\
\zeta_{i}^{-}=\sum_{j=1}^{n} \gamma_{i j}^{-} \times w_{j} \text { and } \sum_{j=1}^{n} w_{j}=1
\end{gathered}
$$

Step 10: Calculating the Relative Grey Relational Grade with regard to IFPIS

Relative grey relational grade of an alternative $A_{i}$ with regard to the intuitionistic fuzzy positive-ideal solution (IFPIS) $\mathrm{A}^{+}$can be calculated as follows:

$$
\varphi_{i}=\frac{\zeta_{i}^{+}}{\zeta_{i}^{+}+\zeta_{i}^{-}}, \text {where } 0 \leq \varphi_{i} \leq 1
$$

\section{Step 11: Sorting the Alternatives}

After determining the relative grey relational grade of each alternative, alternatives are sorted in descending order of $\varphi_{i}$ 's. The larger value of relative grey relational grade of some alternative indicates that it is closer to IFPIS. As a result, the most appropriate choice would be the alternative with the highest closeness value.

\section{Numerical Example of Sustainable Building Materials Supplier Selection}

A housing investment and development company hopes to choose the most suitable supplier in its development process. Five sustainable building materials suppliers have been chosen as alternatives for further consideration and selection. Four criteria are included in the assessment, respectively, as follows:

$\mathrm{C}_{1}$ : Business credit

$\mathrm{C}_{2}$ : Technical capability

$\mathrm{C}_{3}$ : Quality level

$\mathrm{C}_{4}$ : Price 
Step 1: Establishing the Intuitionistic Fuzzy Decision Matrix

We construct decision matrix of intuitionistic fuzzy which contains five alternatives and four criteria. The matrix was showed as follows:

\begin{tabular}{|c|c|c|c|c|}
\hline & $\begin{array}{c}\mathrm{C}_{1} \\
0.15\end{array}$ & $\begin{array}{l}\mathrm{C}_{2} \\
\end{array}$ & $\mathrm{C}_{3}$ & $\begin{array}{c}\mathrm{C}_{4} \\
\end{array}$ \\
\hline & $\begin{array}{l}(0.12,0.151,0.131) \\
(0.628,0.239,0.133)\end{array}$ & $\begin{array}{l}(0.491,0.205,0.240) \\
(0.562,0.197,0.241)\end{array}$ & $(0.582,0.195,0.223)$ & $(0.619,0.205,0.176)$ \\
\hline & 7 & 0.6 & 0.2 & $(0.597,0.196,0.2$ \\
\hline & $(0.691,0.162,0.147)$ & $(0.582,0.201,0.2$ & $(0.609,0.253,0$ & $(0.681,0.192,0.127)^{\circ}$ \\
\hline & (0.586,0.177,0.237) & $(0.627,0.125,0.248)$ & $(0.573,0.181,0.246)$ & $(0.592,0.182,0.22$ \\
\hline
\end{tabular}

where $\mathrm{A}$ denotes the alternative and $\mathrm{C}$ denotes the criterion. In the intuitionistic fuzzy decision matrix, each matrix element is an IFS. For instance, in alternative $A_{1}$, criterion $C_{1}$ has $\mu, v, \pi$ of $(0.712$, $0.157,0.131)$.

Step 2: Determining the Intuitionistic Fuzzy Entropy Values

In this step, for alternative $A_{1}$ in $C_{1}$, we have IFS as $(0.712,0.157,0.131)$, so we calculate the intuitionistic fuzzy entropy values as follows:

$$
\mathrm{E}_{11}\left(\mathrm{x}_{1}\right)=\begin{gathered}
\{\min [0.712,0.157]+\min [1-0.157,1-0.712]\} \\
/\{\max [0.712,0.157]+\max [1-0.157,1-0.712]\}=0.286
\end{gathered}
$$

We performed the same calculation steps for the entire matrix, so the decision matrix becomes the

\begin{tabular}{|c|c|c|c|c|}
\hline & $\mathrm{C}_{1}$ & $\mathrm{C}_{2}$ & $\mathrm{C}_{3}$ & $\mathrm{C}_{4}$ \\
\hline$A_{1}$ & $\lceil 0.286$ & 0.629 & 0.385 & 0.410 \\
\hline$=A_{2}$ & 0.440 & 0.465 & 0.442 & 0.414 \\
\hline & 0.612 & 0.405 & 0.406 & 0.428 \\
\hline $\mathrm{A}_{4}$ & 0.308 & 0.448 & 0.475 & 0.343 \\
\hline$A_{5}$ & $\mathrm{~L}_{0.419}$ & 0.332 & 0.437 & 0.41 \\
\hline
\end{tabular}
following one:

Step 3: Normalizing the Intuitionistic Fuzzy Entropy Value

Then we have to normalize the intuitionistic fuzzy entropy matrix column by column, and the method is to divide the maximum value of each column separately. For instance, in the first column, the maximum value is 0.612 , so all values in the first column must be divided by 0.612 . Therefore, the

\begin{tabular}{|c|c|c|c|c|}
\hline & $\mathrm{C}_{1}$ & $\mathrm{C}_{2}$ & $\mathrm{C}_{3}$ & $\mathrm{C}_{4}$ \\
\hline $\mathrm{A}_{1}$ & {$[0.468$} & 1.000 & 0.811 & $0.960]$ \\
\hline & 0.719 & 0.740 & 0.931 & 0.969 \\
\hline & 1.000 & 0.645 & 0.856 & 1.000 \\
\hline$A_{4}$ & 0.504 & 0.713 & 1.000 & $0.803^{\circ}$ \\
\hline$A_{5}$ & $\mathrm{~L}_{0.686}$ & 0.527 & 0.920 & ] \\
\hline
\end{tabular}
decision matrix becomes the following one:

\section{Step 4: Determining the Criteria Weights}

In this step, we apply the weight function to calculate the criterion weight. For example, we sue $\mathrm{a}_{1}$ and $\mathrm{w}_{1}$. In this numerical study, $\mathrm{n}=4$. The $\mathrm{a}_{\mathrm{j}}$ represents the sum of the normalized entropy values which corresponds to the criterion $\mathrm{j}$. Then $\mathrm{T}$ is the sum of $\mathrm{a}_{\mathrm{j}}$, and $\mathrm{n}$ represents the number of criteria.

$$
\mathrm{a}_{1}=0.468+0.719+1.000+0.504+0.686=3.377
$$


We do the same step for the whole matrix, so the vector $\mathrm{a}_{\mathrm{j}}=\left(\mathrm{a}_{1}, \mathrm{a}_{2}, \mathrm{a}_{3}, \mathrm{a}_{4}\right)=(3.377,3.625,4.517$, 4.711). Then $\mathrm{T}$ and $\mathrm{w}_{1}$ can be obtained as follows.

$$
\begin{aligned}
& T=\sum_{\mathrm{j}}^{4} a_{\mathrm{j}}=3.377+3.625+4.517+4.711=16.229, \\
& w_{1}=\frac{1}{(n-T)} \times\left(1-a_{1}\right)=\frac{1}{(4-16.229)} \times(1-3.377)=0.194
\end{aligned}
$$

As the same step has been done, we can get the weight vector $\mathrm{w}=\left(\mathrm{w}_{1}, \mathrm{w}_{2}, \mathrm{w}_{3}, \mathrm{w}_{4}\right)=$ $(0.194,0.215,0.288,0.303)$.

\section{Step 5: Constructing the Weighted Matrix of Intuitionistic Fuzzy Decision}

Based on the formula (16) proposed by Atanassov (1999), the weighted matrix of intuitionistic fuzzy decision is established.

In this step, for alternative $A_{1}$ in $C_{1}$, we have IFS as $(0.712,0.157,0.131)$, so we calculate the weighted matrix of intuitionistic fuzzy decision as follows:

$$
\begin{aligned}
\mathrm{w}_{1}= & 0.194 \\
\mathrm{D}_{11}^{*}= & \left(\mu_{\mathrm{A} 11 \mathrm{w}_{1}}\left(\mathrm{x}_{1}\right), \mathrm{v}_{\mathrm{A} 11 \mathrm{w}_{1}}\left(\mathrm{x}_{1}\right), \pi_{\mathrm{A} 11 \mathrm{w}_{1}}\left(\mathrm{x}_{1}\right)\right) \\
& =\left\{1-\left(1-\mu_{\mathrm{A} 11}\right)^{\mathrm{w}_{1}},\left(\mathrm{v}_{\mathrm{A} 11}\right)^{\mathrm{w}_{1}}, 1-\left[1-\left(1-\mu_{\mathrm{A} 11}\right)^{\mathrm{w}_{1}}\right]-\left(\mathrm{v}_{\mathrm{A} 11}\right)^{\mathrm{w}_{1}}\right\} \\
& =\left\{1-(1-0.712)^{0.194},(0.157)^{0.194}, 1-\left[1-(1-0.712)^{0.194}\right]-(0.157)^{0.194}\right\} \\
& =(0.215,0.698,0.087)
\end{aligned}
$$

We performed the same calculation steps for the entire matrix, so the weighted decision matrix becomes the following one:

$\left.\begin{array}{rcccc} & \mathrm{C}_{1} & \mathrm{C}_{2} & \mathrm{C}_{3} & \mathrm{C}_{4} \\ \mathrm{~A}_{1} & (0.215,0.698,0.087) & (0.135,0.751,0.114) & (0.247,0.614,0.139) & (0.263,0.629,0.108) \\ \mathrm{D}^{*}=\mathrm{A}_{2} & \mathrm{~A}_{3} \\ \mathrm{~A}_{4} & (0.175,0.757,0.068) & (0.162,0.706,0.132) & (0.222,0.625,0.153) & (0.254,0.618,0.128) \\ \mathrm{A}_{4} & (0.139,0.789,0.072) & (0.184,0.699,0.117) & (0.249,0.638,0.113) & (0.241,0.610,0.149) \\ \mathrm{A}_{5} & (0.204,0.702,0.094) & (0.171,0.709,0.121) & (0.237,0.674,0.090) & (0.293,0.606,0.101)^{\circ} \\ (0.158,0.714,0.128) & (0.191,0.640,0.169) & (0.217,0.612,0.171) & (0.238,0.596,0.166)\end{array}\right]$

Step 6: Acquiring the Solutions of Intuitionistic Fuzzy Positive-Ideal (IFPI) and Intuitionistic Fuzzy Negative-Ideal (IFNI)

"Business credit", "technical capability" and "quality level" are benefit criteria $B=\left\{C_{1}, C_{2}, C_{3}\right\}$ and "price" is cost criteria $C=\left\{\mathrm{C}_{4}\right\}$. Then the solutions of intuitionistic fuzzy positive-ideal (IFPI) and intuitionistic fuzzy negative-ideal (IFNI) were acquired as follows:

$$
\begin{aligned}
& \mathrm{A}^{+}=\{(0.215,0.698,0.087),(0.191,0.640,0.169),(0.249,0.612,0.139),(0.238,0.629,0.133)\} \\
& \mathrm{A}^{-}=\{(0.139,0.789,0.072),(0.135,0.751,0.114),(0.217,0.674,0.109),(0.293,0.596,0.111)\}
\end{aligned}
$$

\section{Step 7: Calculating the Distance Measured from IFPIS (Solution of IFPI) and IFNIS (Solution of IFNI)}

According to normalized Euclidean distance, positive and negative separation measures for each alternative are given in Tables 1 and 2. 
Table 1. Intuitionistic distance measures from IFPIS.

\begin{tabular}{ccccc}
\hline Alternatives & $\mathbf{S}_{\mathbf{c} 1}^{+}$ & $\mathbf{S}_{\mathbf{c} 2}^{+}$ & $\mathbf{S}_{\mathbf{c} 3}^{+}$ & $\mathbf{S}_{\mathbf{c} 4}^{+}$ \\
\hline $\mathrm{A}_{1}$ & 0.0000 & 0.0961 & 0.0020 & 0.0250 \\
$\mathrm{~A}_{2}$ & 0.0522 & 0.0573 & 0.0234 & 0.0142 \\
$\mathrm{~A}_{3}$ & 0.0845 & 0.0558 & 0.0260 & 0.0177 \\
$\mathrm{~A}_{4}$ & 0.0096 & 0.0611 & 0.0565 & 0.0478 \\
$\mathrm{~A}_{5}$ & 0.0509 & 0.0000 & 0.0320 & 0.0330 \\
\hline
\end{tabular}

Table 2. Intuitionistic distance measures from IFNIS.

\begin{tabular}{ccccc}
\hline Alternatives & $\mathbf{S}_{\mathbf{c} 1}^{-}$ & $\mathbf{S}_{\mathbf{c} 2}^{-}$ & $\mathbf{S}_{\mathbf{c} 3}^{-}$ & $\mathbf{S}_{\mathbf{c} 4}^{-}$ \\
\hline $\mathrm{A}_{1}$ & 0.0845 & 0.0000 & 0.0520 & 0.0316 \\
$\mathrm{~A}_{2}$ & 0.0342 & 0.0392 & 0.0467 & 0.0339 \\
$\mathrm{~A}_{3}$ & 0.0000 & 0.0506 & 0.0342 & 0.0466 \\
$\mathrm{~A}_{4}$ & 0.0784 & 0.0394 & 0.0195 & 0.0100 \\
$\mathrm{~A}_{5}$ & 0.0675 & 0.0961 & 0.0620 & 0.0550 \\
\hline
\end{tabular}

Step 8: Calculate Grey Relational Coefficient of Alternatives

Grey relational coefficients, which are calculated by Equation (25) between each alternative and IFPIS, are given as follows:

$$
\gamma_{\mathrm{ij}}^{+}=\left[\begin{array}{llll}
1.0000 & 0.3053 & 0.9548 & 0.6283 \\
0.4475 & 0.4244 & 0.6437 & 0.7488 \\
0.3333 & 0.4308 & 0.6191 & 0.7049 \\
0.8142 & 0.4088 & 0.4278 & 0.4690 \\
0.4535 & 1.0000 & 0.5690 & 0.5615
\end{array}\right]
$$

Grey relational coefficients, which are calculated by Equation (26) between each alternative and IFNIS, are given as follows:

$$
\gamma_{\mathrm{ij}}^{-}=\left[\begin{array}{llll}
0.3626 & 1.0000 & 0.4805 & 0.6033 \\
0.5844 & 0.5506 & 0.5072 & 0.5866 \\
1.0000 & 0.4873 & 0.5844 & 0.5077 \\
0.3802 & 0.5494 & 0.7113 & 0.8278 \\
0.4158 & 0.3333 & 0.4367 & 0.4664
\end{array}\right]
$$

Step 9: Calculating the Grey Relational Grade of Alternatives

Grey relational grades of alternatives calculated by the Equations (27) and (28) are given as follows: 


$$
\begin{aligned}
& \zeta_{1}^{+}=1.0000 \times 0.194+0.3053 \times 0.215+0.9548 \times 0.288+0.6283 \times 0.303=0.7250 \\
& \zeta_{2}^{+}=0.4475 \times 0.194+0.4244 \times 0.215+0.6437 \times 0.288+0.7488 \times 0.303=0.5903 \\
& \zeta_{3}^{+}=0.3333 \times 0.194+0.4308 \times 0.215+0.6191 \times 0.288+0.7049 \times 0.303=0.5491 \\
& \zeta_{4}^{+}=0.8142 \times 0.194+0.4088 \times 0.215+0.4278 \times 0.288+0.4690 \times 0.303=0.5111 \\
& \zeta_{5}^{+}=0.4535 \times 0.194+1.0000 \times 0.215+0.5690 \times 0.288+0.5615 \times 0.303=0.6370 \\
& \zeta_{1}^{-}=0.3626 \times 0.194+1.0000 \times 0.215+0.4805 \times 0.288+0.6033 \times 0.303=0.6065 \\
& \zeta_{2}^{-}=0.5844 \times 0.194+0.5506 \times 0.215+0.5072 \times 0.288+0.5866 \times 0.303=0.5556 \\
& \zeta_{3}^{-}=1.0000 \times 0.194+0.4873 \times 0.215+0.5844 \times 0.288+0.5077 \times 0.303=0.6209 \\
& \zeta_{4}^{-}=0.3802 \times 0.194+0.5494 \times 0.215+0.7113 \times 0.288+0.8278 \times 0.303=0.6476 \\
& \zeta_{5}^{-}=0.4158 \times 0.194+0.3333 \times 0.215+0.4367 \times 0.288+0.4664 \times 0.303=0.4194
\end{aligned}
$$

Step 10: Calculating the Relative Grey Relational Grade with respect to IFPIS

Relative grey relational grade calculated by Equation (29) is shown in Table 3.

Table 3. Relative grey relational grade of the alternatives.

\begin{tabular}{cccccc}
\hline Alternatives & $\mathbf{A}_{\mathbf{1}}$ & $\mathbf{A}_{\mathbf{2}}$ & $\mathbf{A}_{\mathbf{3}}$ & $\mathbf{A}_{\mathbf{4}}$ & $\mathbf{A}_{\mathbf{5}}$ \\
\hline $\boldsymbol{\varphi}_{\mathbf{i}}$ & 0.5445 & 0.5152 & 0.4693 & 0.4411 & 0.6030 \\
\hline
\end{tabular}

\section{Step 11: Sorting the Alternatives}

The relative grey relational grade was calculated and determined, and then alternatives were sorted according to the descending order of $\varphi_{\mathrm{i}}$. The five alternatives were sorted in order as $\mathrm{A}_{5}>$ $A_{1}>A_{2}>A_{3}>A_{4}$, as shown in Table 4 . Among the five alternatives, $A_{5}$ was chosen as appropriate sustainable building materials supplier.

Table 4. The ranking of the alternatives.

\begin{tabular}{cccccc}
\hline Alternatives & $\mathbf{A}_{\mathbf{1}}$ & $\mathbf{A}_{\mathbf{2}}$ & $\mathbf{A}_{\mathbf{3}}$ & $\mathbf{A}_{\mathbf{4}}$ & $\mathbf{A}_{\mathbf{5}}$ \\
\hline Rank & 2 & 3 & 4 & 5 & 1 \\
\hline
\end{tabular}

\section{Results and Discussion}

In this section, findings and sensitivity analysis of this paper will be discussed. From steps $2-4$ in the two stage of the research framework, the intuitionistic fuzzy entropy value of TOPSIS can be derived, which can appropriately replace the subjective weight value set by the decision makers in the traditional TOPSIS method. The obtained value of objective weight vector was $\mathrm{w}=\left(\mathrm{w}_{1}, \mathrm{w}_{2}\right.$, $\left.\mathrm{w}_{3}, \mathrm{w}_{4}\right)=(0.194,0.215,0.288,0.303)$. The implication was that the impact of each criterion on the alternative is $19.4 \%, 21.5 \%, 28.8 \%$, and $30.3 \%$, respectively. Objective weights can be less biased and truly reflect the current conditions than subjective weights. In the third stage, the intuitionistic fuzzy entropy-based TOPSIS method was improved by using the grey relational analysis, and an intuitionistic fuzzy entropy-based TOPSIS-GRA assessment model was established.

In addition, the principle of entropy-based TOPSIS method was used to calculate the superiority of each alternative based on the evaluation index $\varphi_{\mathrm{i}}$. Based on the new established multi-criteria assessment model, the relative grey relational grade $\left(\varphi_{i}\right)$ of the five alternatives were $54.45 \%, 51.52 \%$, 
$46.93 \%, 44.11 \%$, and $60.30 \%$, respectively. According to the $\varphi_{\mathrm{i}}$ values from high to low, we can rank the alternatives in order of $A_{5}, A_{1}, A_{2}, A_{3}, A_{4}$. Finally, it was determined that $A_{5}$ was the optimal supplier.

It can be seen from the results that the research framework proposed in this paper has the advantage of selecting suitable alternatives and providing decision-maker for the ranking with reference value. Furthermore, a systematic sensitivity analysis was performed to verify the stability and robustness of the new assessment model.

First, as described in the previous section in step 8, in addition to Equations (25) and (26) suggested for calculating the recognition coefficient $\rho$, the equations also obtained a crisp value within the limits of $0.1,0.2, \ldots, 1.0$. Hereby, the sensitivity analysis of recognition coefficient $\rho$ can be presented in Table 5 and Figure 2.

Table 5. Sensitivity analysis of the coefficient $\rho$ to the outcome of the alternatives.

\begin{tabular}{lllllllllll}
\hline & $\boldsymbol{\rho}=\mathbf{0 . 1}$ & $\boldsymbol{\rho}=\mathbf{0 . 2}$ & $\boldsymbol{\rho}=\mathbf{0 . 3}$ & $\boldsymbol{\rho}=\mathbf{0 . 4}$ & $\boldsymbol{\rho}=\mathbf{0 . 5}$ & $\boldsymbol{\rho}=\mathbf{0 . 6}$ & $\boldsymbol{\rho}=\mathbf{0 . 7}$ & $\boldsymbol{\rho}=\mathbf{0 . 8}$ & $\boldsymbol{\rho}=\mathbf{0 . 9}$ & $\boldsymbol{\rho}=\mathbf{1 . 0}$ \\
\hline $\mathrm{A}_{1}$ & 0.5978 & 0.5775 & 0.5627 & 0.5522 & 0.5445 & 0.5386 & 0.5340 & 0.5303 & 0.5273 & 0.5248 \\
$\mathrm{~A}_{2}$ & 0.5485 & 0.5333 & 0.5246 & 0.5190 & 0.5152 & 0.5124 & 0.5104 & 0.5089 & 0.5077 & 0.5067 \\
$\mathrm{~A}_{3}$ & 0.3845 & 0.4356 & 0.4542 & 0.4636 & 0.4693 & 0.4732 & 0.4760 & 0.4781 & 0.4799 & 0.4813 \\
$\mathrm{~A}_{4}$ & 0.3941 & 0.4116 & 0.4242 & 0.4337 & 0.4411 & 0.4471 & 0.4519 & 0.4560 & 0.4594 & 0.4624 \\
$\mathrm{~A}_{5}$ & 0.7409 & 0.6737 & 0.6396 & 0.6181 & 0.6030 & 0.5916 & 0.5826 & 0.5753 & 0.5693 & 0.5642 \\
\hline
\end{tabular}

Table 5 and Figure 2 display the relative grey relational grade of the alternatives determined by the value of the recognition coefficient $\rho$. It can be observed that, except for $\rho=0.1$, the values of the remaining recognition coefficients $\rho$ did not affect the ranking of the alternatives, and continued to maintain their starting rank, as displayed in Table 4. As the value of $\rho$ increased, the relative grey relational grade values of rank first to third alternatives decreased, while the values of rank fourth to fifth increased. Figure 3 shows the relative grey relational grade of the alternatives determined by the weight value of each criterion within the range of $-50 \%,-40 \%, \ldots, 40 \%$, and $50 \%$.

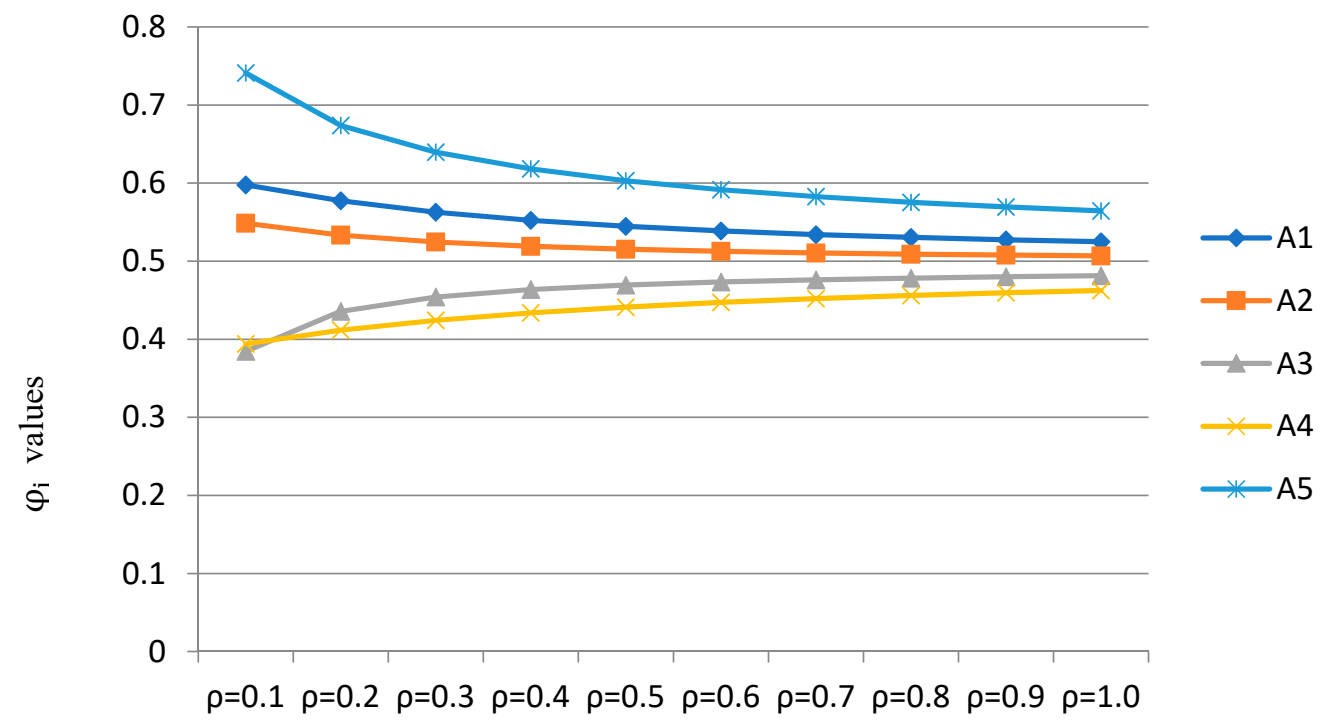

Figure 2. Sensitivity analysis of the recognition coefficient $\rho$ to the outcome of the alternatives.

From the perspective of selecting the optimal alternative, C2 was the sensitive factor. Regardless of how the criterion weight changed, except $\mathrm{C} 2$ (see Figure $3 \mathrm{~b}$ ), the most appropriate choice remained $\mathrm{A}_{5}$. In summary, through a series of sensitivity analysis, it is proven that the evaluation results of the new established assessment model are reliable and effective. The stability, feasibility and effectiveness of the new multi-criteria assessment model for a MCDM problem is verified by the practice of sensitivity analysis of sustainable building materials suppliers. 


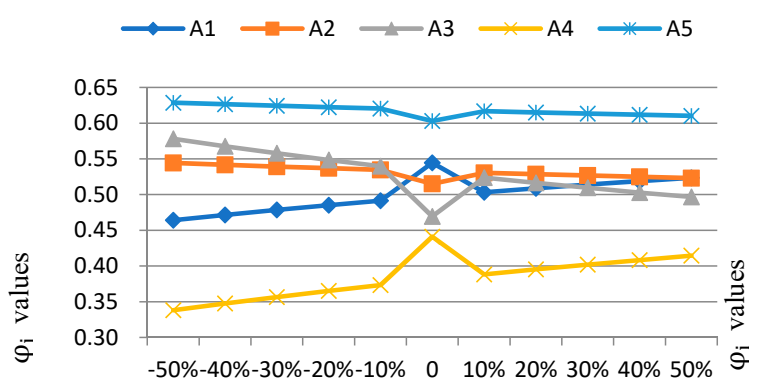

(a) Fluctuation of $\mathrm{C} 1$ weight.

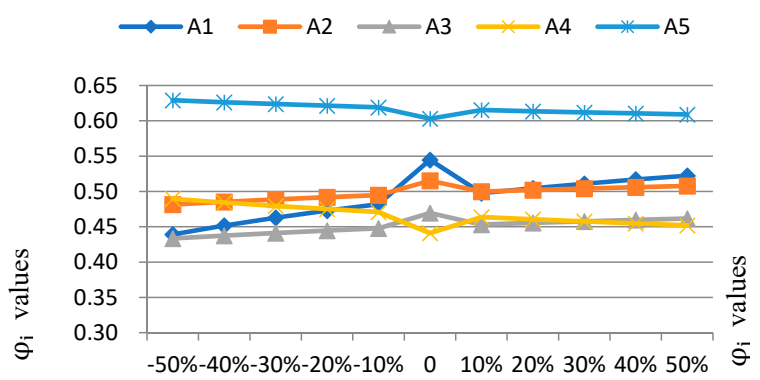

(c) Fluctuation of $\mathrm{C} 3$ weight.

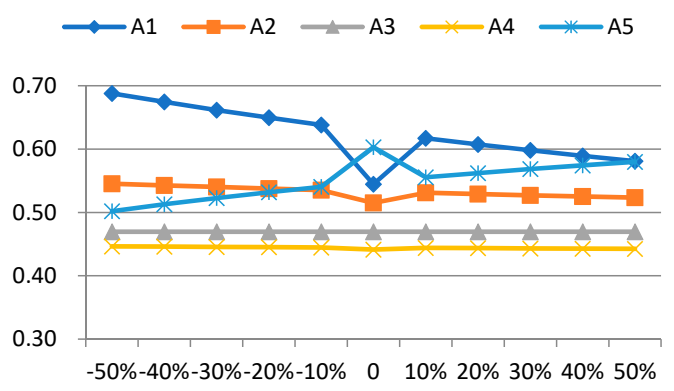

(b) Fluctuation of $\mathrm{C} 2$ weight.

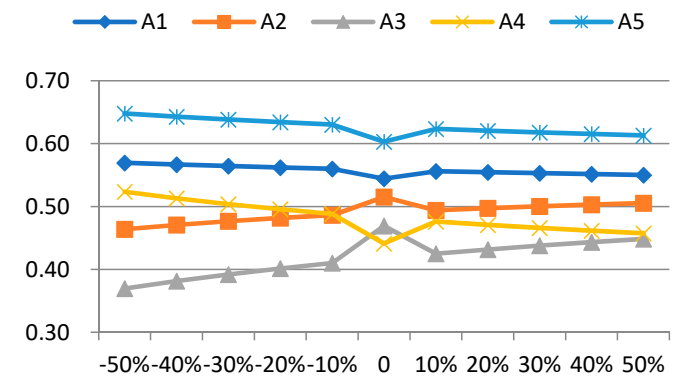

(d) Fluctuation of $\mathrm{C} 4$ weight.

Figure 3. Sensitivity analysis of the criterion weight to the outcome of the alternatives.

\section{Conclusions}

The main contributions of this paper can be stated as follows:

(1) The first contribution is to combine the intuitionistic fuzzy set with the TOPSIS method to become an appropriate MCDM solution. When there is a lack of data and insufficient information, and decision makers are in intuitionistic fuzzy environment.

(2) The second contribution is the objective weight value calculated by the intuitionistic fuzzy entropy to replace the subjective weight that decision makers set directly in the TOPSIS method. In other words, the objective weight of the intuitionistic fuzzy entropy is used instead of the subjective weight, which reduces the bias that may be caused by the subjective judgment.

(3) The third contribution is to extend TOPSIS method with both GRA techniques and intuitionistic fuzzy sets. The weighted matrix is transformed into a grey relational coefficient matrix by introducing the grey relational coefficient, and the closeness between each alternative and the positive-ideal solution is calculated. The closeness is used as the evaluation basis for appropriate supplier selection.

The traditionally weighted TOPSIS method only calculates the relative distance to the ideal solution, but ignores the curve trend and cannot accurately reflect the reality. This paper proposes a new multi-criteria assessment model, combining GRA techniques with intuitionistic fuzzy entropy-based TOPSIS method, for sustainable building materials supplier selection and takes the sustainable building materials supplier as an example to verify the feasibility and effectiveness of the model by a series of sensitivity analysis.

Intuitionistic fuzzy sets are a suitable method for dealing with uncertainty. According to the Euclidean distance, intuitionistic fuzzy positive-ideal solution (IFPIS) and intuitionistic fuzzy negative-ideal solution (IFNIS) were calculated. Then the grey relational coefficient, grey relational grade and relative grey relational grade of five alternatives were obtained, and five alternatives were sorted in descending order.

Findings of this paper contain three portions: (1) in the TOPSIS method, the value of intutionistic fuzzy entropy can appropriately replace the subjective weight value set by the decision makers; (2) 
changes in most of the coefficient $\rho$ values in GRA techniques do not affect the ranking result of the alternatives; and (3) the evaluation results of the new assessment model are reliable and effective.

The entropy-based TOPSIS method integrated with intuitionistic fuzzy set and GRA techniques has great opportunities for success in multi-criteria decision-making because it implies a relatively objective, intuitive and vague perception of the opinions of decision makers. As a result, in the future, the new multi-criteria assessment model can be used to handle fuzzy and uncertainties in multi-criteria decision-making topics such as planning choices, construction options, site selection, and management decision issues in many other areas.

Funding: This research received no external funding.

Conflicts of Interest: The author declares no conflict of interest.

\section{References}

1. Atanassov, K.T. Intuitionistic fuzzy sets. Fuzzy Set Syst. 1986, 20, 87-96. [CrossRef]

2. Atanassov, K.T. More on Intuitionistic fuzzy sets. Fuzzy Sets Syst. 1989, 33, 37-46. [CrossRef]

3. Atanassov, K.T. Two theorems for intuitionistic fuzzy sets. Fuzzy Sets Syst. 2000, 110, 267-269. [CrossRef]

4. Zadeh, L.A. Fuzzy sets. Inf. Control. 1965, 8, 338-356. [CrossRef]

5. Deng, J.L. Introduction to Grey System. J. Grey Syst.-UK 1989, 1, 1-24.

6. Wei, G. Grey relational analysis model for dynamic hybrid multiple attribute decision making. Knowl.-Based Syst. 2011, 24, 672-679. [CrossRef]

7. Liu, S.F.; Guo, T.B.; Dang, Y.G. Grey System Theory and its Application, 2nd ed.; Science Press: Beijing, China, 1999.

8. Wei, G.W.; Zhao, X.F.; Wang, H.J.; Lin, R. GRA model for selecting an ERP system in trapezoidal intuitionistic fuzzy setting. Inf. Int. J. 2010, 13, 1143-1148.

9. Olson, D.L.; Wu, D.S. Simulation of fuzzy multi-attribute models for grey relationships. Eur. J. Oper. Res. 2006, 175, 111-120. [CrossRef]

10. Wu, D.S. Supplier selection in a fuzzy group decision making setting: A method using grey related analysis and Dempster-Shafer theory. Expert Syst. Appl. 2009, 36, 8892-8899. [CrossRef]

11. Rao, C.J.; Xiao, X.P. Novel combinatorial algorithm for the problems of fuzzy grey multi-attribute group decision making. J. Syst. Eng. Electron. 2007, 18, 774-780.

12. Rao, C.J.; Zhao, Y. Multi-attribute decision making model based on optimal membership and relative entropy. J. Syst. Eng. Electron. 2009, 20, 537-542.

13. Rao, C.J. Group decision making model based on grey relational analysis. J. Grey Syst.-UK 2009, 21, 15-24.

14. Rao, C.J.; Zhao, Y. Multi-attribute auction method based on grey relational degree of hybrid sequences. J. Grey Syst.-UK 2009, 21, 175-184.

15. Wei, G.W.; Wang, H.J.; Lin, R.; Zhao, X.F. Grey relational analysis method for intuitionistic fuzzy multiple attribute decision making with preference information on alternatives. Int. J. Comput. Int. Syst. 2011, 4, 164-173. [CrossRef]

16. Ha, S.H.; Krishnan, R. A hybrid approach to supplier selection for the maintenance of a competitive supply chain. Expert Syst. Appl. 2008, 34, 1303-1311. [CrossRef]

17. Chou, S.Y.; Chang, Y.H. A decision support system for supplier selection based on a strategy-aligned fuzzy SMART approach. Expert Syst. Appl. 2008, 34, 2241-2253. [CrossRef]

18. Stevenson, W.J. Operations Management; McGraw-Hill: New York, NY, USA, 2005.

19. Heizer, J.; Render, B. Principles of Operations Management; Prentice-Hall: Upper Saddle River, NJ, USA, 2004.

20. Simchi-Levi, D.; Kaminsky, P.; Simchi-Levi, E. Designing and Managing the Supply Chain: Concepts, Strategies, and Case Studies; McGraw-Hill: New York, NY, USA, 2003.

21. Monczka, R.; Trent, R.; Handfield, R. Purchasing and Supply Chain Management, 2nd ed.; South-Western College Publishing: Cincinnati, OH, USA, 2001.

22. Stojić, G.; Stević, Ž.; Antuchevičienè, J.; Pamučar, D.; Vasiljević, M. A novel rough WASPAS approach for supplier selection in a company manufacturing PVC carpentry products. Information 2018, 9, 121. [CrossRef]

23. Cakravasia, A.; Takahashi, K. Integrated model for supplier selection and negotiation in a make-to-order environment. Int. J. Prod. Res. 2004, 42, 4457-4474. [CrossRef] 
24. Porter, M.E.; Millar, V.E. How information gives you competitive advantage. Harv. Bus. Rev. 1985, 63, 149-160.

25. Giunipero, L.C.; Brand, R.R. Purchasing's role in supply chain management. Int. J. Logist. Manag. 1996, 7 , 29-38. [CrossRef]

26. Haq, A.N.; Kannan, G. Fuzzy analytical hierarchy process for evaluating and selecting a vendor in a supply chain model. Int. J. Adv. Manuf. Tech. 2006, 29, 826-835.

27. Timmerman, E. An approach to vendor performance evaluation. J. Purch. Supply Manag. 1986, 1, $27-32$. [CrossRef]

28. Zenz, G. Purchasing and the Management of Materials; Wiley: New York, NY, USA, 1981.

29. Thompson, K. Vendor profile analysis. J. Purch. Mater. Manag. 1990, 26, 11-18. [CrossRef]

30. Soukup, W.R. Supplier selection strategies. J. Purch. Mater. Manag. 1987, 23, 7-12. [CrossRef]

31. Gregory, R.E. Source selection: A matrix approach. J. Purch. Mater. Manag. 1986, 22, 24-29. [CrossRef]

32. Barbarosoglu, G.; Yazgac, T. An application of the analytic hierarchy process to the supplier selection problem. Prod. Inv. Manag. J. 1997, 38, 14-21.

33. Nydick, R.L.; Hill, R.P. Using the Analytic Hierarchy Process to structure the supplier selection procedure. Int. J. Purch. Mater. Manag. 1992, 28, 31-36. [CrossRef]

34. Tong, L.; Pu, Z.; Ma, J. Maintenance supplier evaluation and selection for safe and sustainable production in the chemical industry: A case study. Sustainability 2019, 11, 1533. [CrossRef]

35. Guo, Z.; Liu, H.; Zhang, D.; Yang, J. Green supplier evaluation and selection in apparel manufacturing using a fuzzy multi-criteria decision-making approach. Sustainability 2017, 9, 650.

36. Ghorabaee, K.M.; Amiri, M.; Zavadskas, E.K.; Antucheviciene, J. Supplier evaluation and selection in fuzzy environment: A review of MADM approaches. Econ. Res. 2017, 30, 1073-1118.

37. Shi, H.; Quan, M.Y.; Liu, H.C.; Duan, C.Y. A novel integrated approach for green supplier selection with interval-valued intuitionistic uncertain linguistic information: A case study in the agri-food industry. Sustainability 2018, 10, 733. [CrossRef]

38. De Boer, L.; Van der Wegen, L.; Telgen, J. Outranking methods in support of supplier selection. Eur. J. Purch. Supply Manag. 1998, 4, 109-118. [CrossRef]

39. Zhang, D.; Zhang, J.; Lai, K.K.; Lu, Y. An novel approach to supplier selection based on vague sets group decision. Expert Syst. Appl. 2009, 36, 9557-9563. [CrossRef]

40. Chen, C.T.; Lin, C.T.; Huang, S.F. A fuzzy approach for supplier evaluation and selection in supply chain management. Int. J. Prod. Econ. 2006, 102, 289-301. [CrossRef]

41. Holt, G.D. Which contractor selection methodology? Int. J. Proj. Manag. 1998, 16, 153-164. [CrossRef]

42. Li, D.F.; Fun, Y.P.; Huang, J.S. A new measure for supplier performance evaluation. Iie Trans. Oper. Eng. 1997, 29, 753-758. [CrossRef]

43. Bayrak, M.Y.; Celebi, N.; Taskin, H. A fuzzy approach method for supplier selection. Prod. Plan. Control Manag. Oper. 2007, 18, 54-63. [CrossRef]

44. Chan, F.T.S.; Kumar, N.; Tiwari, M.K.; Lau, H.C.W.; Choy, K.L. Global supplier selection: A fuzzy-AHP approach. Int. J. Prod. Res. 2008, 46, 3825-3857. [CrossRef]

45. Hwang, C.L.; Yoon, K. Multiple Attribute Decision Making: Methods and Applications; Springer: New York, NY, USA, 1981.

46. Sirisawat, P.; Kiatcharoenpol, T. Fuzzy AHP-TOPSIS approaches to prioritizing solutions for reverse logistics barriers. Comput. Ind. Eng. 2018, 117, 303-318. [CrossRef]

47. Pérez-Domínguez, L.; Luviano-Cruz, D.; Valles-Rosales, D.; Hernández, J.I.H.; Borbón, M.I.R. Hesitant Fuzzy Linguistic Term and TOPSIS to Assess Lean Performance. Appl. Sci. 2019, 9, 873. [CrossRef]

48. Olson, D.L. Comparison of weight in TOPSIS models. Math. Comput. Model. 2004, 40, 721-727. [CrossRef]

49. Chen, C.H. Application Enterprise Architecture and TOPSIS Evaluation Methods for Decision Optimization of Real Estate Investment Projects. In Proceedings of the 2015 Corporate Architecture and Information Technology Seminar, Takming University of Science and Technology, Taipei, Taiwan, 31 October 2015; p. A:1-8.

50. Wang, C.N.; Huang, Y.F.; Chai, Y.C.; Van Thanh, N. A multi-criteria decision making (MCDM) for renewable energy plants locations selection in Vietnam under a fuzzy environment. Appl. Sci. 2018, 8, 2069. [CrossRef]

51. Wang, P. QoS-aware web services selection with intuitionistic fuzzy set under consumer's vague perception. Expert Syst Appl. 2009, 36, 4460-4466. [CrossRef] 
52. Liu, H.W.; Wang, G.J. Multi-criteria decision-making methods based on intuitionistic fuzzy sets. Eur. J. Oper. Res. 2007, 179, 220-233. [CrossRef]

53. Atanassov, K.; Pasi, G.; Yager, R.R. Intuitionistic fuzzy interpretations of multi-criteria multi-person and multi-measurement tool decision making. Int. J. Syst. Sci. 2005, 36, 859-868. [CrossRef]

54. $\mathrm{Xu}, \mathrm{Z}$.S. Intuitionistic preference relations and their application in group decision making. Inf. Sci. 2007, 177, 2363-2379. [CrossRef]

55. Xu, Z.S. Some similarity measures of intuitionistic fuzzy sets and their applications to multiple attribute decision making. Fuzzy Optim. Decis. Ma. 2007, 6, 109-121. [CrossRef]

56. $\mathrm{Xu}, \mathrm{Z}$.S. Models for multiple attribute decision making with intuitionistic fuzzy information. Int. J. Uncertain. Fuzz. 2007, 15, 285-297. [CrossRef]

57. Xu, Z.S.; Yager, R.R. Some geometric aggregation operators based on intuitionistic fuzzy sets. Int. J. Gen. Syst. 2006, 35, 417-433. [CrossRef]

58. Xu, Z.S.; Yager, R.R. Dynamic intuitionistic fuzzy multi-attribute decision making. Int. J. Approx. Reason. 2008, 48, 246-262. [CrossRef]

59. Szmidt, E.; Kacprzyk, J. Using intuitionistic fuzzy sets in group decision making. Control Cybern. 2002, 31, 1037-1053.

60. Szmidt, E.; Kacprzyk, J. A consensus-reaching process under intuitionistic fuzzy preference relations. Int. J. Intell. Syst. 2003, 18, 837-852. [CrossRef]

61. Hong, D.H.; Choi, C.H. Multi criteria fuzzy decision-making problems based on Hausdorff distance. Pattern Recogn. Lett. 2000, 23, 221-225.

62. Chen, S.M.; Tan, J.M. Handling multi criteria fuzzy decision-making problems based on vague set theory. Fuzzy Set Syst. 1994, 67, 163-172. [CrossRef]

63. Valchos, I.K.; Sergiadis, G.D. Intuitionistic fuzzy information-Applications to pattern recognition. Pattern Recogn. Lett. 2007, 28, 197-206. [CrossRef]

64. Zhang, C.Y.; Fu, H.Y. Similarity measures on three kinds of fuzzy sets. Pattern Recogn. Lett. 2006, 27, 1307-1317. [CrossRef]

65. Wang, W.Q.; Xin, X.L. Distance measure between intuitionistic fuzzy sets. Pattern Recogn. Lett. 2005, 26, 2063-2069. [CrossRef]

66. Huang, W.L.; Yang, M.S. Similarity measures of intuitionistic fuzzy sets based on Hausdorff distance. Pattern Recogn. Lett. 2004, 25, 1603-1611. [CrossRef]

67. Liang, Z.Z.; Shi, P.F. Similarity measures on intuitionistic fuzzy sets. Pattern Recogn. Lett. 2003, 24, $2687-2693$. [CrossRef]

68. Li, D.F.; Cheng, C.T. New similarity measures of intuitionistic fuzzy sets and application to pattern recognitions. Pattern Recogn. Lett. 2002, 23, 221-225.

69. Szmidt, E.; Kacprzyk, J. A similarity measure for intuitionistic fuzzy sets and its application in supporting medical diagnostic reasoning. Lect. Notes Comput. Sci. 2004, 3070, 388-393.

70. Szmidt, E.; Kacprzyk, J. Intuitionistic fuzzy sets in some medical applications. Lect. Notes Comput. Sci. 2001, 2206, 148-151.

71. De, S.K.; Biswas, R.; Roy, A.R. An application of intuitionistic fuzzy sets in medical diagnosis. Fuzzy Set Syst. 2001, 117, 209-213. [CrossRef]

72. Deng, J.L. Introduction to Grey System Theory. Syst. Control Lett. 1982, 1, 288-294.

73. Ertugrul, I. Grey relational analysis approach in academic performance comparison of university: A case study of Turkey Universities. Eur. Sci. J. 2016, 12, 128-139.

74. Chang, C.L.; Tsai, C.H.; Chen, L. Applying grey relational analysis to the Decathlon evaluation model. Int. J. Comput. Internet Manag. 2003, 11, 54-62.

75. Kung, C.Y.; Wen, K.L. Applying grey relational analysis and grey decision making to evaluate the relationship between company attributes and its financial performance- a case study of venture capital enterprises in Taiwan. Decis. Support Syst. 2007, 43, 842-852. [CrossRef]

76. Wei, G.W. GRA method for multiple attribute decision making with incomplete weight information in intuitionistic fuzzy setting. Knowl.-Based Syst. 2010, 23, 243-247. [CrossRef]

77. Kuo, Y.; Yang, T.; Huang, G.W. The use of grey relational analysis in solving multiple attribute decision-making problems. Comput. Ind. Eng. 2008, 55, 80-93. [CrossRef] 
78. Lin, C.L.; Lin, J.L.; Ko, T.C. Optimization of the EDM process based on the orthogonal array with fuzzy logic and grey relational analysis method. Int. J. Adv. Manuf. Tech. 2002, 19, 271-277. [CrossRef]

79. Yang, C.C.; Ou, S.L.; Hsu, L.C. A hybrid multi-criteria decision-making model for evaluation companies' green credit rating. Sustainability 2019, 11, 1506. [CrossRef]

80. Chen, C.H. Grey relational method aided decision for projects of interior design. J. Lan Yang Inst. Tech. 2009, 8, 31-39.

81. Chen, C.H. Application of grey relational model to evaluate projects of landscape ecological planning. J. Plan. 2007, 34, 29-47.

82. Wei, G.W. Grey relational analysis method for intuitionistic fuzzy multiple attribute decision making. Expert Syst. Appl. 2011, 38, 11671-11677. [CrossRef]

83. Shu, M.S.; Cheng, C.H.; Chang, J.R. Using intuitionistic fuzzy sets for fault-tree analysis on printed circuit board assembly. Micorelectron. Reliab. 2006, 46, 2139-2148. [CrossRef]

84. Chen, T.Y.; Li, C.H. A comparative analysis of objective weighting methods with intuitionistic fuzzy entropy measures. J. Chin. Inst. Ind. Eng. 2009, 26, 469-479. [CrossRef]

85. Vlachos, I.K.; Sergiadis, G.D. Subsethood, entropy, and cardinality for interval-valued fuzzy sets an algebraic derivation. Fuzzy Set Syst. 2007, 158, 1384-1396. [CrossRef]

86. Chen, T.Y.; Li, C.H. Determining objective weights with instuitionistic fuzzy entropy measures: A comparative analysis. Inf. Sci. 2010, 180, 4207-4222. [CrossRef]

87. Atanassov, K. New operations defined over the intuitionistic fuzzy sets. Fuzzy Set Syst. 1999, 61, 137-142. [CrossRef]

88. Szmidt, E.; Kacprzyk, J. Distance between intuitionistic fuzzy sets. Fuzzy Set Syst. 2000, 114, 505-518. [CrossRef]

(C) 2019 by the author. Licensee MDPI, Basel, Switzerland. This article is an open access article distributed under the terms and conditions of the Creative Commons Attribution (CC BY) license (http://creativecommons.org/licenses/by/4.0/). 